\title{
ENVIRONMENTAL KUZNETS CURVE: THE CASE OF CANADA, SPAIN AND INDONESIAN ON $\mathrm{CO}_{2}$ EMISSION
}

\author{
Erwinsyah \\ Magister Program of Mathematics and Natural Science Education, \\ Universitas Indraprasta PGRI, \\ Email: erwinsyah.unindra@gmail.com
}

\begin{abstract}
The Environmental Kuznets Curve is used to investigate the relationship between various indicators of environmental degradation and income per capita. The economic growth measured from the change of income per capita contributes negative externalities to nature, and education contributes to better knowledge for sustainable development. The purpose of this research was to apply the Environmental Kuznets Curve to see the impact of income per capita and education on environmental degradation. The objective of this research was to examine how GDP per capita and education contribute to per capita $\mathrm{CO}_{2}$ emission in Canada, Spain, and Indonesia. The research output showed a relationship between per capita GDP with per capita $\mathrm{CO}_{2}$ emission in Canada and Spain. Contribution of per capita GDP to per capita $\mathrm{CO}_{2}$ emission of Canada higher than Spain. The higher per capita GDP will rise per capita $\mathrm{CO}_{2}$ emission. The per capita GDP of Indonesia does did contribute significantly to per capita $\mathrm{CO}_{2}$ emission. The was also a significant relationship between education quality and per capita $\mathrm{CO}_{2}$ emission in Canada, Spain, and Indonesia. The better education quality in Canada and Spain contribute to lower per capita $\mathrm{CO}_{2}$ emissions. Education quality in Indonesia contributed to the higher per capita $\mathrm{CO}_{2}$ emission.
\end{abstract}

Keywords: Environmental Kuznets Curve, Per Capita CO2 Emission, Per Capita GDP, Education

\section{INTRODUCTION}

Economic growth is valuable in achieving people's welfare for a better quality of standard of living. Meanwhile, the development impacts become more crucial, especially to gradual increase threats to the environment like climate change, deforestation, and pollution, and more severe in developing countries. According to some research, a weak regulation in developing countries contributes the pollutant production (Dinda, 2004). Good quality education is an essential tool in supporting better knowledge generated by science and used in sustainable development practices to minimalize the pollution impact on the environment. Education involves a permanent process of acquiring new knowledge, soft skills, know-how, and good manners (Dinda, 2004). Education has been considered an essential element for environmental protection, encourages 
behavior and lifestyle changes in favor of the environment, and increases public awareness and knowledge about environmental issues (Romuald, S., Education, K., Dioxide, C., \& African, C., 2012), can be used as one of the emissionreduction tool strategies (Wynes, S., \& Nicholas, K. A.,2018).

Currently, global warming has emerged as one of the biggest environmental challenges due to greenhouse gas emissions, and nearly 60 percent of greenhouse gas emissions resulting from human activity or anthropogenic matter. (Uusitalo, A., Uusitalo, V., Grönman, A., Luoranen, M., \& Jaatinen-Värri, A., 2016). Carbon dioxide $\left(\mathrm{CO}_{2}\right)$ is widely reported as one of the important greenhouse gases $(\mathrm{GHG})$ and a primary threat to the environment. Global warming is associated with the contribution of 50 percent $\mathrm{CO}_{2}$ to the anthropogenic greenhouse effect (Demirbas, M. F., Bozbas, K., \& Balat, M. (2004).

Canada produced greenhouse gas emissions 22 percent higher than they had been around ten years earlier (Environment Canada, 2014), a contribution to the global emission of 1.6 percent. Other contributions from European Union 28 (EU-28) countries contribute to the emission of 9.1 percent, and Spain was one of the largest contributors to the union of 8 percent $\mathrm{CO} 2$ emissions (Crippa, M., Oreggioni, G., D, G., Muntean, M., Schaaf, E., Lo Vullo, E., Solazzo, E., MonfortiFerrario, F., Olivier, J. G. ., \& Vignati, E., 2019). Indonesia is a developing country with high species diversity and tropical rain forests, but also one of the most vulnerable countries to climate change effects (Saboori, B., Sulaiman, J. Bin, \& Mohd, S. (2012), in 2014, Indonesia was one of the world largest contributor country carbon emissions after the United States, the European Union, China, India, and Russia (Nasih, M., Harymawan, I., Paramitasari, Y. I., \& Handayani, A., 2019), including due to the degraded of its forests and carbon-rich peatlands.
Canada, a developed country with a high per capita gross domestic product (GDP) of USD 51,476, Spain's per capita GDP of USD 32,897, and Indonesia's per capita GDP of USD 4,284 in 2018 (Constant 2010 US\$), represent a different level of economic growth. Besides one of the high economic growth countries, Canada also has excellent educational quality (Morgan, C., 2011). Spain has reformed its educational system, and brought the country to the international standards of education quality, bringing the country as benchmarks for school system stands (Engel, L. C., \& Rutkowski, D., 2014), while with the complexity of the problems, the education quality in Indonesia still below the international standards, especially for the college graduates (Sulisworo, D., 2016).

In many countries, economic development very often contributes impact to environmental degradation, far from the implementation of the principles of sustainability. Education brings better knowledge and behavior to both enhancing economic growth and the possibility of natural destruction or sustainable development. The Environmental Kuznets Curve figuring the relationship between pollution levels and income where the pollution will increase due to higher government income, and the threshold of income will eventually be reached, beyond which pollution levels will decrease. Some countries may take increases in pollution with increased economic development, but others may implement sustainable development practices (Franklin, R. S., \& Ruth, M., 2012).

The purpose of this research was to apply the Environmental Kuznets Curve (EKC) to see the impact of income per capita and education on environmental degradation. The objective of this research was to examine how per capita GDP and education contribute to per capita $\mathrm{CO}_{2}$ emission in Canada, Spain, and Indonesia. This research used time-series data covers from 1990 to 2018 which including per 
capita $\mathrm{CO}_{2}$ emission, per capita GDP (with constant 2010 US\$) taken from the World Bank, and education index from the UNDP.

\section{RESEARCH METHODS}

The EKC model in this research was developed and adjusted based on Ahmed, K., \& Long, W. (2012) with the following equation:

$\operatorname{Ln} E_{\mathrm{t}}=\alpha 0+\alpha 1 \ln Y_{t}+\alpha 2\left(\ln Y_{t}\right)^{2}+\alpha 3 \ln E D_{t}+\varepsilon_{t} \ldots$

Where $\mathrm{E}$ is per capita $\mathrm{CO}_{2}$ emission, $\mathrm{Y}$ represents per capita real income, ED is education index, and $\varepsilon$ is the standard error term. Education has identified as a significant factor influencing household per capita $\mathrm{CO}_{2}$ emissions (Crippa, M., Oreggioni, G., D, G., Muntean, M., Schaaf, E., Lo Vullo, E., Solazzo, E., MonfortiFerrario, F., Olivier, J. G. ., \& Vignati, E., 2019). Based on the EKC hypothesis, the sign of $\alpha 1$ expected to be a positive sign and negative for $\alpha 2$, or vice versa. Higher education refers to the use of technology contributing to higher economic activity and stimulates $\mathrm{CO} 2$ emissions, $\alpha 3$ expected to be positive, or vice versa. For the econometrical analysis, the equation then formulated as follows.:

$\Delta \mathrm{Ln} E_{\mathrm{t}}=\alpha_{0}+\sum_{k=1}^{n} \alpha 1 \mathrm{k} \Delta \ln Y_{\mathrm{t}-\mathrm{k}}+\sum_{k=1}^{n} \alpha 2 \mathrm{k} \Delta\left(\ln Y_{\mathrm{t}-\mathrm{k}}\right)^{2}$ $+\sum_{k=1}^{n} \alpha 3 \mathrm{k} \Delta \ln \mathrm{EDID}_{\mathrm{t}-\mathrm{k}}+\varepsilon_{t}$

The stationarity test was used to see the long-run relationship between variables of per capita $\mathrm{CO}_{2}$ emission, per capita GDP, and education. The time-series data of the variables was tested by Augmented Dickey-Fuller (ADF) and Phillips-Perron (PP) Tests. For the next step, the estimated equation was examined to see the consistency of regression by the Johansen Cointegration Test. The serial correlation was tested by using a residual diagnostic of the Breusch-Godfrey Serial Correlation LM Test to see the autocorrelation of the timeseries data. The Breusch-Pagan-Godfrey Test was used to examine for heteroskedasticity. After the data prerequisite was tested and accepted, then proceed to find out the estimated EKC equation by ordinary least square (OLS) method to see how per capita GDP and education contribute to per capita $\mathrm{CO}_{2}$ emission. The EViews Software was used for these econometric tests and estimate the estimated long-run equations.

\section{RESULTS ANALYSIS}

\section{Data Description}

The average per capita $\mathrm{CO}_{2}$ emission produced by Canada from 1990 to 2018 was 21.94 metric tons, higher than produced by Spain of 8.47 metric tons, and higher than by Indonesia of 2.96 metric tons. The per capita $\mathrm{CO}_{2}$ emission in Canada was higher than in the emission production in Spain and Indonesia, respectively shown in Figure 1 . The increasing trend of the per capita $\mathrm{CO}_{2}$ maintained in few of the larger volume of $\mathrm{CO}_{2}$ emissions produced in the group of high income developed countries than those in Europe and Central Asia region (Ota, T., 2017).

There was an average per capita GDP of Canada from 1990 to 2018 of US\$ 42,444 , higher than Spain's per capita GDP of US\$ 37,652 and Indonesia's per capita GDP of US\$ 2,723. The per capita GDP of Canada was higher than the per capita GDP of Spain and both per capita GDP far higher than the per capita GDP of Indonesia. About the quality of education from 1990 to 2018, Canada was higher than in Spain and Indonesia, respectively. The average education index during that timeseries data was 0.84 for Canada, 0.73 for Spain, and 0.53 for Indonesia. The higher education index is the better quality of education. The quality of education in Canada was better than in Spain and Indonesia, and Spain was better than in Indonesia. Both per capita GDP and the education quality of Canada higher than Spain and Indonesia, respectively, are shown in Figure 2. 


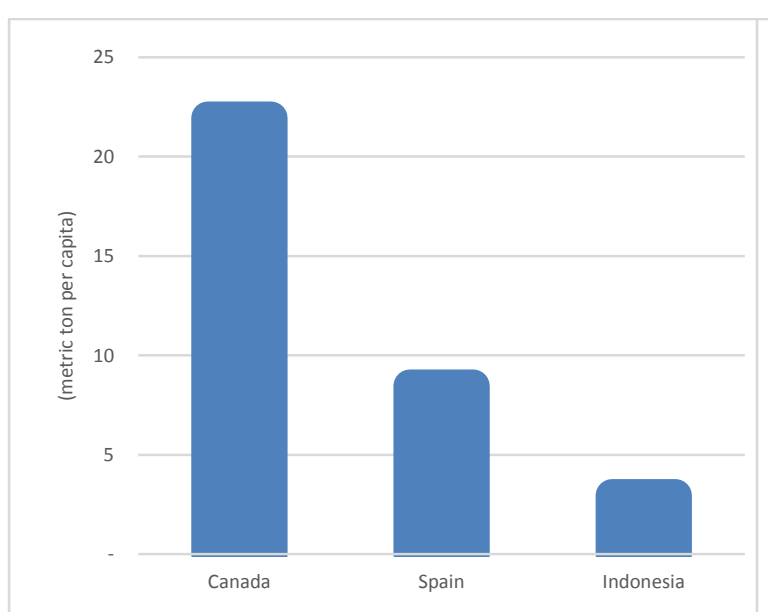

Figure 1. Per capita $\mathrm{CO}_{2}$ Emission 1990-2018

\section{The role of Economic Growth and Education on $\mathrm{CO}_{2}$ Emissions}

The time-series data tested to investigate the presence of a unit root of the variables with the Augmented DickeyFuller (ADF) and Phillips-Perron (PP) tests of EViews Statistical Data Processing. The null hypothesis of the time series data is the

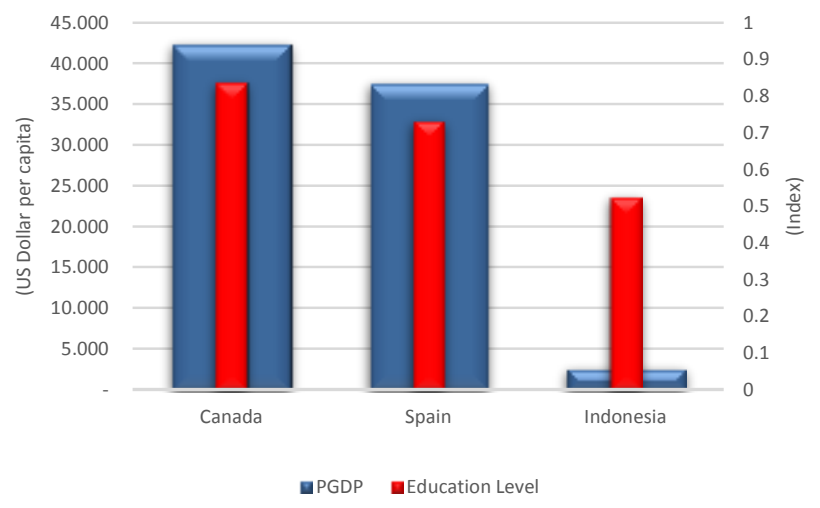

Figure 2. Per capita GDP and Education 1990-2018

presence of a unit root, and the alternatives hypothesis is stationarity. The result of the ADF and PP unit root test shows in Table 1. It shows that variables are stationary at the first difference for Canada and Indonesia, and the second difference for Spain, and the variables then ready for the cointegration test.

Table 1. Unit Root Tests

\begin{tabular}{|c|c|c|c|c|c|c|}
\hline \multicolumn{7}{|c|}{ Group Unit Test Summary } \\
\hline \multicolumn{7}{|c|}{ Series: $\ln P C O 2, \ln P G D P, \ln$ PGDP $^{2}, \operatorname{lnEDID}$} \\
\hline \multirow[t]{2}{*}{ Method } & \multicolumn{2}{|c|}{ Canada } & \multicolumn{2}{|c|}{ Spain } & \multicolumn{2}{|c|}{ Indonesia } \\
\hline & Statistic & Prob.** & Statistic & Prob.** & Statistic & Prob.** \\
\hline Null: Unit roo & assumes c & mon unit & process) & & & \\
\hline $\begin{array}{l}\text { ADF - Fisher } \\
\text { Chi-square }\end{array}$ & 51.1733 & 0.0000 & 38.4841 & 0.0000 & 50.1748 & 0.0000 \\
\hline $\begin{array}{l}\text { PP - Fisher } \\
\text { Chi-square }\end{array}$ & 70.6446 & 0.0000 & 39.0409 & 0.0000 & 50.7476 & 0.0000 \\
\hline
\end{tabular}

** Probabilities for Fisher tests are computed using an asymptotic Chi-square distribution. All other tests assume asymptotic normality.

The cointegration test aims to examine the possible correlation between several time-series data. The null hypothesis of the time-series data was a nocointegration equation against the alternative of a cointegration equation. The Johansen Cointegration Test shows the rejection of a null hypothesis of nocointegration and accepted a cointegration equation at the 0.05 level of Canada, Spain, and Indonesia with lags of interval in 1st differences. Result of the cointegration test shown in Table 2. 
Table 2. Unrestricted Cointegration Rank Test (Trace)

\begin{tabular}{lcccccc}
\hline Hypothesized & \multicolumn{2}{c}{ Canada } & \multicolumn{2}{c}{ Spain } & \multicolumn{2}{c}{ Indonesia } \\
\cline { 2 - 6 } No. of CE(s) & 0.05 & Prob.** & 0.05 & Prob.** & 0.05 & Prob.** \\
& Critical & & Critical & & Critical \\
& Value & & Value & & \\
\hline None & 47.85613 & $0.0006^{*}$ & 47.85613 & $0.0000^{*}$ & 47.85613 & $0.0002^{*}$ \\
At most1 & 29.79707 & $0.0124^{*}$ & 29.79707 & $0.0191^{*}$ & 29.79707 & $0.0213 *$ \\
At most2 & 15.49471 & $0.0189^{*}$ & 15.49471 & $0.0484 *$ & 15.49471 & 0.0581 \\
At most3 & 3.841466 & 0.0543 & 3.841466 & 0.2141 & 3.841466 & 0.9344 \\
\hline
\end{tabular}

Trace test indicates 3 cointegration eqn(s) of Canada and Spain, and 2 cointegration eqn(s) of Indonesia at the 0.05 level

*denotes rejection of the hypothesis at the 0.05 level

** MacKinnon-Haug-Milles (1999) p-values

The autocorrelation test for this research used the Breusch-Godfrey Serial Correlation LM Test. For Canada, the Breusch-Godfrey Serial Correlation LM Test with the result of Prob. Chi-Square $0.25>0.05$, or more than $\alpha$ of 5 percent. It indicated to accept Ho, so there is no autocorrelation. The normality test of the probability $0.12>0.05$, or more than $\alpha$ of 5 percent, so the data distribution is normal. The Heteroskedasticity Test BreuschPagan-Godfrey results in a Probability of Chi-Square (3) $0.14>0.05$, or more than $\alpha$ of 5 percent, so there is no heteroskedasticity.

For Spain, the Breusch-Godfrey Serial Correlation LM Test with the result of Prob. Chi-square (with a one-period lag of dependent variable of $\ln \mathrm{PCO} 2$ ) $0.14>$ 0.05 , or more than $\alpha$ of 5 percent). It indicated to accept Ho, so there is no autocorrelation. The normality test with the probability $0.37>0.05$, or more than $\alpha$ of percent, means the distribution is normal. Heteroskedasticity Test Breusch-PaganGodfrey with the Probability of Chi-Square (5) $0.1044>0.05$, or more than $\alpha$ of 5 percent, which means no heteroskedasticity.

For Indonesia, the Breusch-Godfrey Serial Correlation LM Test with the result Prob. Chi-square is $0.31>0.05$, or more than $\alpha$ of 5 percent, then to accept Ho, means no autocorrelation. The normality test with the probability of $0.64>0.05$, or more than $\alpha$ of 5 percent, means the distribution is normal. Heteroskedasticity Test Breusch-Pagan-Godfrey with the probability of Chi-Square (4) $0.0507>$ 0.05 , or more than $\alpha$ of 5 percent, means no heteroskedasticity.

Proven that there was no autocorrelation, and data with normally distributed, and no heteroskedasticity. The estimated equations with the OLS method and the coefficient of the equation shown in Table 3. The estimated equation of the EKC for each country is as follows:

Canada: $\operatorname{lnPCO} 2=-121.6147+23.45304 * \ln P G D P-$ $1.1025661 *(\operatorname{lnPGDP})^{2}-0.053126 * \operatorname{lnEDID} \ldots$... (3)

Spain: $\operatorname{lnPCO} 2=-20.01687+0.710210 * \ln P C O 2(-$ $1)+3.614362 * \ln P G D P-0.158057 *(\ln P G D P) 2-$ $0.640039 * \ln E D I D$

Indonesia: $\operatorname{lnPCO} 2=2.625979-1.710428 * \ln P G D P$ $+0.067289 *(\ln P G D P) 2+0.203271 * \ln E D I D$

Table 3. Estimated coefficient of variables for EKC

\begin{tabular}{|c|c|c|c|c|c|c|}
\hline \multicolumn{7}{|c|}{ Dependent Variable: $\ln \mathrm{PCO}_{2}$} \\
\hline \multirow[t]{2}{*}{ Variable } & \multicolumn{2}{|c|}{ Canada } & \multicolumn{2}{|c|}{ Spain } & \multicolumn{2}{|c|}{ Indonesia } \\
\hline & Coefficient & Prob. & Coefficient & Prob. & Coefficient & Prob. \\
\hline $\mathrm{C}$ & -121.6147 & 0.0510 & -20.01687 & 0.1288 & 2.625979 & 0.4219 \\
\hline $\operatorname{lnPCO} 2(-1)$ & - & - & 0.710210 & 0.0001 & - & - \\
\hline $\ln P G D P$ & 23.45304 & $0.0474 * *$ & 3.614362 & $0.1260 *$ & -1.710428 & 0.3816 \\
\hline$(\operatorname{lnPGDP})^{2}$ & -1.1025661 & $0.0487 * *$ & -0.158057 & $0.1260 *$ & 0.067289 & 0.1874 \\
\hline $\operatorname{lnEDID}$ & -0.053126 & 0.9155 & -0.640039 & $0.0648 *$ & 0.203271 & $0.0000 * *$ \\
\hline
\end{tabular}




\section{INTERPRETATION}

Referring to Table 3, for a long-term relationship of the different sign-on lnPGDP with (lnPGDP) ${ }^{2}$ shows the inverted U-shaped relationship between per capita $\mathrm{CO}_{2}$ emission and per capita GDP. The estimated linear model shows in a natural logarithm form. The value 23.4 per capita GDP of Canada denotes that the increase in 1 percent per capita GDP will raise the 23.4 percent per capita $\mathrm{CO}_{2}$ emission. The value 3.6 per capita GDP of Spain indicates that the increase in 1 percent per capita GDP will increase the 3.6 percent per capita $\mathrm{CO}_{2}$ emission. Canada is including one of the very successful countries in implementing the development program and contributed to the country's economic growth. Among the top key industry sectors were including real estate, manufacturing, mining, Finance, and Construction (Government of Canada, 2020). While agriculture (including livestock) contributes to around 2.7 percent of Spanish GDP, the industrial sector (including textiles, food processing, iron and steel, and naval machine and engineering) accounts for 20.2 percent of GDP, and the tertiary sector (including tourism) contributes to 67.9 percent of GDP (Nordea Bank Abp., 2020). These development activities contributed to the per capita $\mathrm{CO}_{2}$ emission in Canada and Spain. The contribution of per capita GDP to per capita $\mathrm{CO}_{2}$ emission of Canada higher than Spain. The per capita GDP of Indonesia did not contribute significantly to per capita $\mathrm{CO}_{2}$ emission.

For a long-term relationship, the estimated linear model presented in a natural logarithm form with the value 0.05 education of Canada denotes that the increase in 1 percent education quality will reduce 0.05 percent per capita $\mathrm{CO}_{2}$ emission. The value 0.6 education of Spain indicates that the increase in 1 percent education quality in Spain will reduce 0.6 percent per capita $\mathrm{CO}_{2}$ emission, and the value 0.2 education of Indonesia denotes the increase in 1 percent education quality will produce 0.2 percent per capita $\mathrm{CO}_{2}$ emission. Canada, one of the countries that have an excellent quality of education, and Spain has brought the country to the highest standard of education quality. Education in Canada could contribute to better environmental impact but less than in Spain, meaning that education in Spain more contributes effectively to reduce $\mathrm{CO}_{2}$ emission than in Canada. Education in Indonesia is still below the quality of education in Canada and Spain, where education is still contributing to the higher per capita $\mathrm{CO}_{2}$ emission.

\section{CONCLUSION}

There was a significant relationship between per capita GDP and per capita $\mathrm{CO} 2$ emission in Canada and Spain, but not significantly in Indonesia. The higher per capita GDP in Canada and Spain produces more per capita $\mathrm{CO} 2$ emissions. The was also a significant relationship between education quality and per capita $\mathrm{CO}_{2}$ emission in Canada, Spain, and Indonesia. The better education quality in Canada and Spain contribute to lower per capita $\mathrm{CO}_{2}$ emissions. Education quality in Indonesia contributed to the higher per capita $\mathrm{CO}_{2}$ emission.

\section{REFERENCES}

Ahmed, K., \& Long, W. (2012). Environmental Kuznets Curve and Pakistan: An Empirical Analysis. Procedia Economics and Finance, 1(12), 4-13. https://doi.org/10.1016/s22125671(12)00003-2

Crippa, M., Oreggioni, G., D, G., Muntean, M., Schaaf, E., Lo Vullo, E., Solazzo, E., Monforti-Ferrario, F., Olivier, J. G. ., \& Vignati, E. (2019). Fossil $\mathrm{CO} 2$ and GHG emissions of all world countries - 2019 Report Publications Office of the EU. https://doi.org/10.2760/687800

Demirbas, M. F., Bozbas, K., \& Balat, M. (2004). Carbon dioxide emission trends and environmental problems in 
Turkey. Energy Exploration and Exploitation, 22(5), 355-366. https://doi.org/10.1260/01445980430 26464

Dinda, S. (2004). Environmental Kuznets Curve hypothesis: A survey. Ecological Economics, 49(4), 431455.

https://doi.org/10.1016/j.ecolecon.20 04.02.011

Engel, L. C., \& Rutkowski, D. (2014). Global influences on national definitions of quality education: Examples from Spain and Italy. Policy Futures in Education, 12(6), 769-783.

https://doi.org/10.2304/pfie.2014.12.6 .769

Franklin, R. S., \& Ruth, M. (2012). NIH Public Access. Appl Geogr, 32(1), 29-39.

https://doi.org/10.1016/j.apgeog.2010 .10.014Morgan, C. (2011). Education in Canada : in Pursuit of Educational Qualityand Equity. Revista Española de Educación Comparada, 0(18), 125-156.

https://doi.org/10.5944/reec.18.2011. 7560

Government of Canada. (2020). Gross domestic product (GDP) at basic prices, by industry, annual average ( $\mathrm{x}$ 1,000,000). Statistics Canada. https://doi.org/https://doi.org/10.2531 8/3610043401-eng

Nasih, M., Harymawan, I., Paramitasari, Y. I., \& Handayani, A. (2019). Carbon emissions, firm size, and corporate governance structure: Evidence from the mining and agricultural industries in Indonesia. Sustainability (Switzerland), 11(9). https://doi.org/10.3390/su11092483

Nordea Bank Abp. (2020). The economic context of Spain. Spain: Economic and Political Overview. https://www.nordeatrade.com/fi/expl ore-new-market/spain/economicalcontext
Ota, T. (2017). Economic growth, income inequality and environment: assessing the applicability of the Kuznets hypotheses to Asia. Palgrave Communications, 3(1). https://doi.org/10.1057/palcomms.20 17.69

Romuald, S., Education, K., Dioxide, C., \& African, C. (2012). Education , Convergence and Carbon Dioxide Growth per Capita Somlanaré Romuald Kinda To cite this version : HAL Id : halshs-00684315 Education , Convergence and Carbon Dioxide Growth per Capita.

Saboori, B., Sulaiman, J. Bin, \& Mohd, S. (2012). An Empirical Analysis of the Environmental Kuznets Curve for $\mathrm{CO} 2$ Emissions in Indonesia: The Role of Energy Consumption and Foreign Trade. International Journal of Economics and Finance, 4(2), 243-251.

https://doi.org/10.5539/ijef.v4n2p243

Sulisworo, D. (2016). The Contribution of the Education System Quality to Improve the Nation's Competitiveness of Indonesia. Journal of Education and Learning (EduLearn), 10(2), 127. https://doi.org/10.11591/edulearn.v10 i2.3468

Uusitalo, A., Uusitalo, V., Grönman, A., Luoranen, M., \& Jaatinen-Värri, A. (2016). Greenhouse gas reduction potential by producing electricity from biogas engine waste heat using organic Rankine cycle. Journal of Cleaner Production, 127, 399-405. https://doi.org/10.1016/j.jclepro.2016. 03.125

Wynes, S., \& Nicholas, K. A. (2018). Reply to Second comment on "The climate mitigation gap: Education and government recommendations miss the most effective individual actions." Environmental Research Letters, 13(6). https://doi.org/10.1088/17489326/aac9cf 